\title{
Anti-Americanism in Europe: Causes and Consequences
}

\author{
Alida Tomja \\ University "Aleksandër Moisiu", Durrës, Albania \\ Email: alidatomja@hotmail.com, alidatomja@uamd.edu.al
}

\section{Doi:10.5901/mjss.2013.v4n3p259}

\begin{abstract}
Even though the subject of anti-Americanism has been addressed in the political literature in Europe and other regions of the world, it has sparked enough interest, especially after the tragic events of 11 September, 2001. Americano-phobia and antiAmericanism are the strangest prejudices in modern history and even in theoretical doctrinal principles. Thus, the aim of this article is to understand its source and consequences. We also must be able to see anti- Americanism in Europe as an indicator of European culture, rather than the fault of U.S. policies. Historically, Europeans have been among the strongest friends of the United States, and for many that tradition continues. In the case of Albania "special relationship" remains valid even after Albania appears to be more pro-American nation in the world, followed by Kosovo Albanians. But there is also, a European predisposition to vilify the United States. Then, what is the source of anti-Americanism? This paper elaborates it. To realize this research is used the method of literature and documentation survey making efforts to have objective and accurate sources of information. Through literature review, I tend to explain how to understand anti-Americanism and Americano-phobia, the geographical distribution of anti and pro-American sentiments and above all, to portray the causes and consequences of the European anti-Americanism.
\end{abstract}

Keywords: Anti-Americanism, Americano-phobia, America, Europe, Culture.

\section{Introduction}

America, being what it is, do not leave anyone indifferent...It motivates great admiration, sympathy, gratitude, but also jealousy, frustration, need for protection but also need for independence (Paemen 2003). Taking into account the words of Hugo Paemen, I would say that the United States of America from their creation, have either loved or hated. These main trens were noticed: on one hand there were people who admired America. Its people and its way of life on the other hand, there were people who had worried the role that America has played and continues to play in the global scene (Tarifa 2008: 27). But what should we mean by anti-Americanism, is this a clear notion and well defined? Does Americano-phobia has the same impact as anti-Americanism? When I ask about this topic, I do not think that antiAmerican sentiments were so deep, so old, even that had arisen with the discovery of America. Reading Fatos Tarifa, Denis Lacorne, Hubert Vedrine, Philippe Roger, James W. Ceaser and many others, I found out that anti-American sentiments or earlier negative stereotypes about were fed in 1700s, by the pseudoscientific theory of Comte de Buffon who linked the degeneration and deficiency of the "New World" with its very wet climate. Precisely these completely irrational and absurd stereotypes have given life to Americano-phobia which in the view of the French author, Denis Lacorne, distinguished anti-Americanism. He said: "By anti-Americanism, I mean the critical and reasoned expression of a disagreement with what Americans say or do. By Americano-phobia, I mean the total visceral rejection of anything that has to do with American culture, democracy, or economy, in short, with American civilization" (Lacorne 2005). David Ellwood, defines anti-Americanism as a cultural and political phenomenon which we can understand only by being familiar with its history, studying the evolution of all forms of antagonism toward the nation, people, civilization and the actions taken by United States of America. Meanwhile, for Fatos Tarifa, anti-Americanism is a negative predisposition, or a kind of ambiguity, which in most cases has not base objective or content. Anti-Americanism is a certain attitude (Tarifa 2008: 27).

Personally I think that anti-Americanism and Americano-phobia reflect different reactions to the United States and which therefore have different impacts on the latter. While I see anti-Americanism as a reflection of thoughts, opinions on the most critical cases, such as unfavorable judgments against the United States or its policies; I see Americano-phobia as a reflection of prejudice, as distortion of information predisposition to believe only the negative about the United States. At the same time, as long as I understand anti-Americanism as opinion, then there is the possibility that the latter be changed while the phobia against America, for me it's hard to influence. In this regard, Americano-phobia perceived as 
bias, misrepresentation of information, has major consequences on the long term on the United States, on their foreign policy, rather than anti-Americanism understood as a particular opinion. But things are not so simple. AntiAmericanism is a very vague concept for which there is no single definition. Moreover some authors talk about different types of anti-Americanism, for its variety forms. However, the main aim of this paper is to understand the source and consequences of anti-Americanism, if it should be considered just one event, a cause, or a result in the transatlantic disruption. But let's get acquainted below with the history and the spread of anti-American sentiments in Europe, to understand better this phenomenon.

\section{A Brief Historical Overview}

European Anti-Americanism is a sentiment that has existed since the creation of America itself. Since then, European scholars have discussed about America and have even discoed without visited it a single time. Negative prejudices about America and Americans are not new. In an article written by James W. Ceaser "A Genealogy of AntiAmericanism" (Ceaser 2003), we can find a mosaic of negative stereotypes, paradoxical prejudices on the United States and the lives of Americans which have started since the mid- eighteenth century. Since at this time starts the whole history of anti-Americanism in Europe, a history which has adversely affected the transatlantic relationship, an absurd history but also harmful.

According to naturalists Buffon, Corneulius de Pouw and their "degeneration thesis", nobody could live in the "New World" whose discovery was the biggest tragedy that happened to mankind (Diner 1996: 3-4). Their absurd prejudices, adversely affected the subsequent European intellectuals dominating in most of the XIX century. During this century, European aristocracy hated America because it had become a symbol of progress, innovation and above all equality of opportunity. Precisely when this new nation created the American model of populist democracy, increase mass culture and spread industrialization, then Europe began to see America as a viral threat that could destabilize the established order in the old continent. Already, America accused of what would call excessive civilization, which will further feed Americano-phobia and anti-Americanism. As Fatos Tarifa notes, European anti-Americanism of this period, has been generally and consistently associated with social, cultural and political conservatism, with efforts to preserve old traditions and the protest against modernity (Tarifa 2008: 38).

After the Second World War until the end of the Cold War American domination became less abstract. At this time is supposed that America was dominating the world and should have done do so. American foreign policy, the pressure of modernization, as well as being dollar empire, returned to the feeding force of anti-Americanism. An obvious fear of this hegemonic began to distort Europe, for over France during the first decade after the war. Mainly, European leftists mostly fed negative sentiments towards the United States which ranged from dislike up to irritation or antipathy. At this time, anti-Americanism became the hallmark of official policy of France which was feeling the fear of losing its cultural supremacy that it has enjoyed since that time. Anti-Americanism of this period especially in ' 70 years, was more oriented to American culture, only later was supplemented by the antipathy to American state and policy. In short fear over this so powerful country that was changing all the balances that existed since that time, was modernizing everything, that was dominating everywhere, fueled anti-American sentiments in postwar Europe.

Later, with the collapse of the Soviet Union and the end of the Cold War, America became the sole superpower, being simultaneously the object of contempt and criticism, of disgust and even the envy of Europe. What is interesting relates to the paradox that has always accompanied America, at the same time this country has been the most offended and the most coveted; and"samples" and the desired model. Anti-American sentiments in Europe were strengthened at the precise time when the opposite was expected. Before 1989 America was the "protective umbrella" of Western Europe but after the collapse of the Soviet Union, the United States became undesirable in Europe and especially in France. America began to be seen as damaging and dominant superpower, as a towering model of civilization, as a diseases collection of westernising and globalization (Rubin 2004). Anti-Americanism of this period was often connect with global movements, with the fear of world domination by the capitalist interests and American culture (Barber 1996).

After the events of 11 September 2001, Western Europe's antipathy toward the United States, leaves the turn to solidarity for the tragic events that shocked not only America. But soon, this solidarity faded to be replaced by old systemic disease of Europe, anti-Americanism. In many aspects, terrorist attacks of September 11, were fundamentally anti-American acts, which meet all the definitions of anti-Americanism. Therefore, not in vain Theodore Zeldin has defined anti-Americanism as a pathology which explains these events. He wrote: To hate a whole nation, to love a whole nation, is a clear syndrome of hysteria (cited in Lacorne, D., Jacques R. \& Marie-France T. 1990: 35). 
At the time of the outbreak of war in Iraq, it was born a new wave of anti-Americanism, which resulted mainly from strong feelings against the war that had some European countries. Western Europe, especially France and Germany, were inclined to see America as selfish and irresponsible, which according to them was risking the country to strengthen its Security Foreign policy pursued at this period by the W. Bush administration, led to the creation of rather than a negative image for America to European countries.

While today, the strengthen role of the United States as sole superpower in the world has risen and spread cultural, socio-economic and political anti-Americanism in Europe. The gap between Europeans and Americans has grown so much as France and Germany, are in charge of exporting countries for the anti-American sentiments. But how are spread anti-American sentiments in Europe, ultimately, are all Europeans anti-American? Let 's handle this issue below.

\section{The Spread of Anti-American Sentiments in Europe}

All the kinds of anti-Americanism, are played with variouse melodies and rhythm in all states of Europe ... (Katzenstein \& Keohane 2007: 57). Not only Peter J. Katzenstein and Robert O. Keohane speak with such an argument but Andrei Markovits asserts that all forms of anti-Americanism as a naturalist, cultural, socio-economic and political, can be found throughout Europe. This author, quoting Sigmund Freud, according to which"Yes, America is gigantic, but a gigantic mistake", and Charles Dickens, mocking the notion that America should arouse envy throughout the world (Markovits 2007: 56-73) argues that what is at play is in reality a pan-European discourse of anti-Americanism , rather than a country specific one (ibid: 28), in terms of its form and content, as well as its analytical foundation, concepts, and political and social functions (Markovits 2007: 46). I think that this argument applied by Andrei Markovits worth to be taken into account to some extent, but not without reservations. First of all, it is clear that while anti-American sentiments are widespread around the world, they remain vulnerable in Europe more than anywhere else, prevalent in Western Europe, more than in the Islamic world and as I would like to point out, still more in France, which is defined as the epicenter of European anti-Americanism elits (Katzenstein \& Keohane 2007: 36). But the problem is that while for this author, antiamericanism is a pan-European phenomenon, for other authors as Hugo Paemen, in Europe there is no general antiAmericanism. Even if we speak with the words of the former Polish Defense Minister Radek Sikorski, cited by Fatos Tarifa, in some European countries like France, anti-Americanism is endemic, widespread, while in other countries, for example in Poland, it almost does not exist (cited in Tarifa 2008: 77). But what can we say about anti-Americanism in Germany, Britain or other European countries? Meanwhile, French anti-Americanism is not understandable, considering the fact that France has never been at war with the United States, by contrast, have been allied, the anti-American sentiments of Germany, Russia, Spain or England, I think can be somewhat acceptable or justified. According to Russell Barmann the case of Germany is such that anti-Americanism and filo-Americanism exist side by side. While it shares common values with Americans, she can nurture anti-Western and anti-American subculture, as happened after 11 September 2001 (Barman 2004: 34). Personally, I see the German and French attitudes toward the United States, not only in terms of direct assessment of the policy of the latter, whether past or future, but as a consequence of the assessment that the Germans and French have for the their role in world affairs. Today's unipolar system, has left them a space in which neither Germany nor France are satisfied.

Of course, not all Europeans are anti-American, but we must be aware that in certain circumstances, some European politicians choose to play the "anti-Americanism card" where they are more expedient, especially in the circumstances of their election. As happened with Jasques Chirac and Gerhard Schröder in Germany in 2002, who by following this strategy reached to win the elections. Gerhard Schröder, German Chancellor accused the only world's superpower, that it was not an "organized state." In 2002, he built his election campaign, criticizing the wrong policies of the United States, especially the Administration of the President George W. Bush. He fielded himself as anti-American supporting the President Jacques Chirac, and the President Vladimir Putin to counter American hegemony. However, Europe has historically enjoyed close relations with the United States, a relationship that no other part of the world has had such at that level. The whole concept of "New World" versus "Old World", despite the common values they share, as Richard Pells notes, originated in Europe, and as such is carved in the form of deep convictions European antiAmericanism (Pells 1997: 2-7), making that modernity seen as barbarism, to be a negative and constant perception of Europe to America (Markovits 2007: 46). What we should consider when we talk about Europe, is that we should not perceive it as a single whole homogeneous. European countries represent cultural diversity and cultural, historical and geographical differences. Furthermore, as Fatos Tarifa stated, the similarities in appearance between the European Union, in fact conceal significant cultural differences and quite obvious national identities. He is right in thinking that 
Britain is culturally very similar to the United States than to the European countries like France, Italy, Greece or Poland (Tarifa 2008: 23). However, although it is unclear what they have in common, it is argued that one of the few values that all Europeans share in the moment made against America, is "not being American" (Ash 2004: 54-94). American sentiments, which in various forms have permeated all these countries, have helped Europe to create a self identity against America. Negative perception that Europeans have against cultural, political and economic influence, or security issues in their countries, the rejection to American power, I think that comes from the need of Europe to be more independent in all these areas, either in matters of security,economic issues or diplomatic ones. But on the other side, feeling not ready for this independence, proves at the same time a confrontation of sentiments that revolve around the need to be under American protection at one hand and the need to be independent at the other. Writing these words, I bring to mind Philippe Roger which says, is the feeling of failure and disappointment what makes French, hostile and aggressive (Roger 2005),... maybe this applies to all anti-American Europe.

After we talked so much about European anti-Americanism, may naturally ask, are all Europeans anti-American? Are all Europeans aggressive and hostile to foreign policy, socio-economic system and above all to the American culture that is widely spread in the "era of globalization"? Of course not. It is true that much has been written about anti-American sentiments in the European continent and especially in Western Europe, on the grievance, hatred against America, while very little is spoken about pro-American feelings in Europe, but this does not mean that they not exist. In fact, the relationship between the United States and the countries of Central and Eastern Europe by several authors, is defined as special, meaning here a special and different relationship not just from what the relationships of the United States have been in similar regions but also the relationship that these small countries have historically been with the major powers. In the case of Albania special relationshipremains valid even after Albania appears to be more pro-American nation in the world, followed by Kosovo Albanians (Tarifa 2008: 117). And in fact, that in the early 90s had clear signs that the foreign policy of this country was moving to align with the United States which had strongly supported the democratization of Albania. Not only in the early 90s but today perhaps there is no country in Europe, to have such sympathy for the United States as Albania. However, in most Central European countries, mainly Eastern Europe and Eastern countries of the former communist bloc, the United States are seen as "beacons" of their freedom and democracy. American presence in Europe has always been considered necessary counterweight against the dominant trend of France or Germany. In contrast to Western European, the concern of American cultural domination was not present in Eastern European countries which for many years had to face the Soviet cultural domination and the communist regime. Moreover, American culture is always seen as attractive in these countries. Also in contrast to Western European, the countries of this region seem genuinely grateful to the United States for their freedom, so not in vain are defined by Donald Rumsfeld, former Secretary of Defense of United States, as "New Europe" pro-American. ${ }^{1}$

\section{Causes and Consequences of the European Anti-Americanism}

After the Second World War, relationships between Europe and America, have undergone constant fluctuation, but the size and strength of antipathy towards America today in Europe, exceed the most tense period in relations between the two sides of Atlantic. In the last years, all of us have witnessed the current situation between the Europe and United States. In this situation, anti-Americanism should be see just one event, a cause, or a result in this transatlantic disruption? Anti-American sentiments in Europe, are not only due of the foreign policy of the United States, of their hegemony, military force, or only result of "hatred" of these countries towards Anglo-Saxon socio-economic model that Europe in general has refused to imitate. Andrew Kohut, based on the data of "Pew Global Attitudes Project," found four aspects, which are the central reasons that have led to grow anti-Americanism worldwide and specifically in Europe (Kohut 2007: 5-7):

1. A general perception that the U.S. acts unilaterally in the international arena, failing to take into account the interests of other countries when it makes foreign policy decisions;

2. A broad discomfort with unrivaled American power;

3. A perceived disproportionate willingness to use military force, and especially preemptive force;

4. A rejection of "Americanization" - the wide diffusion of American ideas and customs fueled by globalization.

Recognizing the fact that the causes which have led on the rise of European anti-Americanism are numerous, I would like to stop at those causes which Joseph S. Nye has designated as sources of "soft power" (Nye 2004) in America and include among others, political values and cultural norms. As we know, the United States historically have fought to

${ }^{1}$ A transcript prepared by: Federal News Service INC., Washington, D.C. Secretary Rumsfeld Briefs at the Foreign Press Center. News Transcript. January 22, 2003. 
spread their values throughout the world being somehow self-proclaimed as the universal nation, whose values should be applied universally to all mankind (Lieven 2005: 34). But such an attitude can not pass without challenge and without becoming subject to the criticism of those nations that historically have "competed for the title" having the same aspirate: exporting their values to the rest of the world. From this perspective, it is understandable why the European national creed is colliding with the U.S. national creed, it is understandable why for France has been so difficult to accept the spread of American values throughout the world, it is understandable why European countries feel the need to protect their values and culture and is therefore clear why anti-Americanism is fueled by the so-called "imperialism" of cultural and American values.

Indeed, the idea that America is different from the other countries and belongs the mission of preaching its values in the rest of the world, can be found in all sides of American politics and has been a source of influence on foreign policy of this state. The words of Secretary of State Madeleine Albright, according to which "the American nation is necessary", clearly point to elements of American national identity. Also, through these words we can understand why many Americans are surprised when confronted with anti-American sentiments. The experience of becoming a model for the rest of the world, lies deep in their national consciousness, even claimed that they necessarily require that other nations adopt the same values and virtues of the great nation of the future. All this can be best illustrated by the words of James Skillen, who writes:

"Americans have believed from the beginning that their nation has a divine mission to fulfill, to bring light to the world, a light that was subsequently defined as the light of freedom, democracy, and prosperity rather than the light of biblical righteousness"( Skillen 2005: 78).

The problem lies in the fact that this American national mission is contrary to national interests of anti-American nations in Europe, that not only don't like to be guided by the United States by this "dominant, obnoxious allied, that always act as triumphant, selfish and hegemonic superpower" but they criticize and denounce as controversial the most part of what those latter perceive as values. On this point of view, would be entitled Markovic who emphasizes that the European anti-Americanism relates more to America's identity, thus what America is than its behavior, thus what America does (Markovits 2007: 81-82). In this context, the typical American values, and so more the ones they are trying to export through their foreign policy, have served as a repeated source of European anti-Americanism. Regarding the issue of cultural norms, we can say that the United States of America have become a synonymous with the so-called cultural modernity: American cultural products and norms, have become global in a much greater extent than those of the other countries. As Lieber said, while priority and influence of the United States are easier to assess in the economic and military sphere, in the cultural arena, it becomes more difficult, however, even here, American superiority is really noticeable (Lieber 2055: 101).

In fact, the cultural dimension of the United States "soft power" is very important because the United States, are increasingly seen as the epitome of mass culture. American popular culture, where we can talk about fast food industry popularly known as the American fast-food, pop music, television, Internet pages indicated as computer-based media, constitute the most widespread and prominent exports American, which first became attractive to European people, later to the entire world. Exactly this process has frightened European political and cultural elites, according to which American mass culture poses a serious threat to the "top" culture of the old continent, massive imports of American cultural products are degenerating their own culture. Seen in this light by the European cultural elites, cultural anti-Americanism is growing day by day. This form of anti-Americanism is fed constantly being manifested in the form of rejection of American cultural products on the one hand and constantly criticizing their attractiveness to the peoples of the world, in the other.

However, except the American unilateralism as alleged in the post Cold War world, except the American primacy in everything as a single global hegemony in today's uni-polar system, except the clash of political values, globalization and so on, the causes of European anti-Americanism are constantly fluctuating between historical or current European countries identity and cultural norms confrontation between the two continents, making European anti-Americanism widely perceived as a problem of culture.

\section{Conclusion}

Finally we can say that the close relations between Europe and the United States, today we find really in low level. European anti-Americanism has created tensions and more difficulties to transatlantic relationships. American dominance has generated frustration among those who feel threatened and scared by it and the Europeans are feeling each day and more the need of protecting their culture from Americanization, attempting to resist to the universal tendency of this 
phenomenon. However, Europeans and Americans should realize that they cherish and share common values on the basis of which, should continue to cooperate and provide solutions to global problems.

European anti-Americanism, especially the cultural is not a new phenomenon, two sides of the Atlantic have lived for more than half a century with this problem: the cultural division between a vigorous and masculine America and a sophisticated, feminine Europe, without backbone. However, Europe and America could manage better these differences, as they could afford and the political tension caused between them.

Absolute superiority of the United States in global affairs, especially if this phenomenon is seen in relation to a relative decline of Europe, their unilateral foreign policy, their hegemony, military force, the "hatred" of European countries towards Anglo-Saxon socio-economic model but even more the cultural confrontation between the two continents, remain the main causes that have inflamed and intensified anti-American sentiments in many corridors of European diplomacy and politics, particularly in France, making anti-Americanism almost a global phenomenon.

But what I can say is that anti-Americanism in Europe has affected the transatlantic alliance and if so extended, will only further encourage Americans to give unilateral answers to common global problems. According to my opinion, is the duty of the European states, of the European moderators to refuse and to give up from the basic rhetoric of antiAmericanism, which is harmful in nature and free by any form of rationality.

\section{References}

Ash, Timothy Garton. (2004). Free World. Why a crisis of the West reveals the opportunity of our time. London: Allen Lane. Barman, Russell. A. (2004). Anti-americanism in Europe: A Cultural Problem. Hoover Institution Press: Stanford University. Barber, Benjamin. (1996). Jihad VS. McWorld. New York: Ballantine Books.

Ceaser, James W., (2003), A Genealogy of anti-Americanism, The Public Interest. [Online] Available: http://thepublicinterest.com /archives/2003summer/article1.html (July 7, 2012)

Diner, Dan. (1996). America in the Eyes of Germans. Princeton: Markus Wiener Publishers.

Katzenstein, Peter J. Keohane, Robert O. (2007). Anti-Americanisms in World Politics. Ithaca, NY: Cornell University Press.

Kohut, Andrew. (2007). America's Image in the World: Findings from the Pew Global Attitudes Project. Testimony of Andrew Kohut, President of the Pew Research Center, to the Subcommittee on International Organizations, Human Rights, and Oversight Committee on Foreign Affairs, U.S. House of Representatives, March 14, 2007.

Lacorne, Denis. (2005). Anti-americanismand Americanophobia: A French Prespective. [Online] Available: http://www.cerisciencespo.com/archive/mars05/artdl.pdf ( August 15, 2012.)

Lacorne, D., Jacques R. \& Marie-France T. (1990). The Rise and Fall of Anti-americanism: A Century of French Perception. St. Martin's.

Lieber, Robert J. (2005). The American Era. Power and Strategy for the 21st Century. New York: Cambridge University Press.

Lieven, Anatol. (2005). America Right or Wrong. An Anatomy of American Nationalism. London: Harper Perennial.

Markovits, Andrei S. (2007). Uncouth Nation. Why Europe Dislikes America. Princeton, NJ: Princeton University Press.

Nye, Joseph S. (2004). The Decline of America's Soft Power. Foreign Affairs, Vol. 83 Issue 3.

Paemen, Hugo. (2003). Testimony on "The future Transatlantic Relations: A wiev from Europe" before the U.S House Committee on International Relations, Sub-Committee on Europe, 17 June.

Pells, Richard.(1997). Not Like Us. How Europeans Have Loved, Hated, and Transformed American Culture Since World War II. New York: Basic Books.

Roger, Philippe. (2005). The American Enemy: The History of French Anti-americanism. Chicago: The University of Chicago Press.

Rubin, Judy C. (2004). The Five Stages of anti-Americanism. Foreign Policy Research Institute. [Online] Available: www.fpri.org/enotes I20040904.americawar.colprubin.5stagesantiamericanism.html (July 10, 2012.)

Sikorski, Radek. (2003). Testimony at a hearing session on "The Future of Transatlantic Relations: A view of Europe" before the U.S House Committeeon International Relations, Sub-committee on Europe, June 17.

Skillen, James W. (2005). With or Against the World? America's Role among the Nations. Lanham: Rowman \& Littlefield Publishers.

Tarifa, Fatos. (2008). Amerikanofobia dhe Anti-Amerikanizmi Europian. Tiranë: Ombra GVG. 